\title{
Native American Urban Narratives: Theodore Van Alst's Sacred Smokes and Tommy Orange's There There
}

\section{Abstract}

The article examines the representation of Native American urban identity in Theodore Van Alst's Sacred Smokes (2018) and Tommy Orange's There There (2018). Drawing upon Stuart Hall's and James Clifford's theories of identity and diaspora and Robert Young's distinction between the "organic" and the "diasporizing" modes of hybridity, it analyzes hybrid strategies through which these texts define their characters' complex diasporic experience and extend the literary tradition of "survivance." The paper argues that by exploring the concepts of history, community, and home and by emphasizing the narrative, imaginative, and relational aspects of their characters' traveling identities, Van Alst's and Orange's texts remain strongly rooted in Native cultural perspective, in particular the "synecdochic" sense of self and the literary trope of "homing." It also maintains that these characters' precarious diasporic situation, albeit confining, allows them the freedom to (re)imagine themselves and thereby transcend their unstable deterritorialized and transcultural position and the realities of dispersal and alienation by inventing new modes of self-coherence and cultural continuity.

Keywords: Theodore Van Alst, Sacred Smokes, Tommy Orange, There There, urban Indians, diaspora, identity, hybridity, home, survivance 
In order to be recognized, to claim authenticity in the world - in order to be seen at all - the Indian[s] must conform to an identity imposed from the outside ... their art must be figuratively dressed in braids, beads, and buckskin.

\section{Louis Owens, Mixedblood Messages}

With their focus on contemporary urban settings of Chicago and Oakland and the identity of their diasporic Native communities, the recently published debut texts Sacred Smokes (2018) by Theodore Van Alst (Lakota) and There There (2018) by Tommy Orange (Southern Cheyenne) prove that twenty-first-century American Indian literature is no longer necessarily trapped by the predicament from the epigraph, noted by Louis Owens two decades ago. Yet, even though they are neither "dressed in braids, beads, and buckskin," (Owens 14) since their protagonists' "Indianness" is mainly unobtrusive, blended into a globalized identity and transformed in the deterritorialized metropolitan setting, nor do they draw upon the sacred history and other traditional components of peoplehood - language, ceremonial cycle, and place (cf. Holm et al. 12-13), both texts remain firmly rooted in Native identity and its cultural perspective. With this premise, this paper attempts to map the hybrid strategies and diasporic forms in Sacred Smokes and There There in order to uncover the ways in which, by foregrounding transformation - a foundation of both imagination and self-definition, they reconceptualize urban Indian identity and extend the Native American literary project of decolonization, resistance, and survival.

Both Sacred Smokes and There There exhibit what Young terms the "organic" and the "diasporizing" forms of hybridity. Emphasizing the dual nature of hybridity, Young argues that hybridity "works simultaneously in two ways: 'organically', hegemonizing, creating new spaces, structures, scenes, and 'intentionally', diasporizing, intervening as a form of subversion, translation, transformation" (23). Depicting the experience of the second and third generation of Native urban diaspora, both texts build their "organic" hybridity by emphasizing the fluidity and the narrative foundation of identity. According to Hall, the diasporic identity is an "act of imaginative rediscovery," premised on "the re-telling of the past" ("Cultural Identity and Diaspora" 52), that imposes the "imaginary coherence on the experience of dispersal and fragmentation, which is the history of all enforced diasporas" ("Cultural Identity and Diaspora" 52). "I light a smoke and tell myself stories 
that I hope will keep me sane", admits Teddy, the narrator of Sacred Smokes, revealing that one's sense of self evolves from the way it is narrated and imagined:

Truth in our stories

while maybe not "true,"

it is what makes us ourselves

Truth, subjective sight

what we hear and say at night

salves rubbed on our souls

Truth, whispered aloud

stories told to sharp-eared friends

they know what we say

Truth, never quiet

asks for a voice, to be heard

persisting in us

In remain

there's no main

unless we think

of ourselves

that way. (Van Alst)

Making the "imaginary coherence" from the diasporic experience of dispersal by collecting fragments of urban Indian life narratives is the main purpose of a project undertaken by Dene, one of the protagonists of There There. It is also the central motif that unites the novel's multifarious characters and the theme of the novel itself. Even though it is based on individual interviews with twenty-first-century Oakland Natives, Dene's project is historical and collective in many ways. He inherited the work from his late uncle, who started documenting experiences of urban Natives living 
in Oakland whom he met through a mutual acquaintance, "a kind of auntie ... Indian way"

(Orange). Dene's commitment to the project is also part of his own identity quest and a link to his ancestry - "the short time" he and his uncle had together: "He wanted to believe that when he turned on the camera, his uncle was with him, seeing through it" (Orange). Dene's project is thus multigenerational and communal, and it confirms that "identities are about questions of using the resources of history, language and culture in the process of becoming rather than being: not 'who we are' or 'where we came from', so much as what we might become ... They arise from the narrativization of the self" (Hall, "Who Needs 'Identity'?" 4). "Stories are invaluable," explains Dene,

When you hear stories from people like you, you feel less alone. When you feel less alone, and like you have a community of people behind you, alongside you, I believe you can live a better life.... That's what I'm trying to get out of this whole thing. All put together, all our stories. Because all we got right now are reservation stories, and shitty versions from outdated history textbooks. A lot of us live in cities now. This is just supposed to be like a way to start telling this other story ... the whole picture is not pathetic, and the individual people and stories that you come across are not pathetic or weak or in need of pity. ... (Orange)

Like Dene's project, Orange's novel is a collage of individual stories of urban survival, alienation, and despair, developed around twelve characters of mostly third-generation relocatees living in Oakland, complementing and completing each other in many ways. Like Dene's interviews, they, too, sustain what Friedman terms as a "relational" and Krupat defines as a "dialogic" (qtd. in Wong 14) sense of identity. "One of the last things Mom said to me when we were over there, she said we shouldn't ever not tell our stories," reveals Opal to her sister Jacquie, remembering her mother's words that "the world [is] made of stories ... and stories about stories" (Orange). Emphasizing the formative power of storytelling in Native communities and its relation to cultural identity and survival, Craig Womack maintains that storytelling is a way for "community members to present images of themselves on their own terms" (362). Stories make us visible and tell us "who we are," asserts Leslie Marmon Silko (qtd. in Cullum 130):

The self is defined as a member of the collective through this process of storytelling: "That's how you know you belong / if the stories incorporate you into them. - People tell these stories about 
you and your family or about others and they begin to create your identity. In a sense, you are told who you are, or you know who you are by the stories that are told about you." (qtd. in Browdy de Hernandez 45)

Stories form the basis of kinship, claims Greg Sarris, emphasizing the narrative and communal foundations of Native identity: "[stories] remind us that we are not alone ... [that] "there [are] other people, other stories" (12). Both Dene's interview project and the individual narratives that make up the fabric of Orange's novel uphold the narrative component of Native identity in that they also evoke Vizenor's statement that a people acquire their identity through a mass of little stories, "narrative wisps," as he calls them, drawing upon Lyotard, "stories that one tells, that one hears, that one acts out": "the people does not exist as a subject but as a mass of millions of insignificant and serious little stories that sometimes let themselves be collected together to constitute big stories and sometimes disperse into digressive elements" (qtd. in Vizenor 227). Yet, most of the "narrative wisps" assembled in the novel and Dene's interviews seem to point to their narrators' confusion about their identity. Almost all of these characters' stories are dysfunctional and considered meaningless, illustrative of their profound alienation from their Native community and history. Describing her family, Opal reveals that her sister “Jacquie's last name is Red Feather, and [hers] is Bear Shield" and that both their fathers abandoned their mother after making her the victim of domestic violence (Orange). Later on, Opal insists that her life narrative should not be told: "It's not a story. ... Life doesn't work out the way stories do. Mom's dead, she's not coming back, and we're alone, living with a guy we don't even know who we're supposed to call uncle. What kind of a fucked-up story is that?" (Orange). "My dad never talked about being Native and shit to the point that we don't even know what tribe we are on his side," reveals Calvin, whose mother is also half Native, "but she doesn't know too much about that either":

Yeah and my dad wasn't home hardly ever, then one day he was really gone. He left us. ... he fucked us up as a dad, I don't wanna come off like I think that's what being Native means. I know there's a lot of Natives living in Oakland and in the Bay Area with similar stories. But it's like we can't talk about it because it's not really a Native story, but then it is at the same time. It's fucked up. ... "So you don't feel, like, any kind of Native pride or whatever? ... I just don't think it's right for me to claim being Native if I don't know anything about it. (Orange) 
Borrowing a quote from Gertrude Stein's Everybody's Autobiography, referring to the profound changes of Stein's Oakland childhood home and her realization that the place from her memory does not exist anymore, that "there is no there there," when she visits her old neighborhood years later, Dene suggests that the same has happened to the second and third-generation urban Indian residents whose tribal identity has become blurred to the point of erasure, despite the fact that they still inhabit their ancestral land: "But for Native people in this country, all over the Americas, it's been developed over, buried ancestral land, glass and concrete and wire and steel, unreturnable covered memory. There is no there there" (Orange). Urban Indian stories, shared in both Sacred Smokes and There There, are permeated with the experience of hopelessness, poverty, unemployment, discrimination, displacement, family dissolution, and violence. Severed from their ancestral history and community, not brought up on tribal stories and ceremonies but on popular readings, music, and movies they consume among the urban concrete and along the commuter routes, their protagonists seemingly meet only two criteria of James Clifford's definition of diaspora - "history of dispersal" and "alienation," (305) and it seems that, indeed, "there is no there there." These characters' disturbing stories mirror a "pattern of frustration, despair, alienation, apathy, and suicidal behavior" (Clark 286) - typical among the urban Native population across the U.S. - and are inseparable from the historical experience of colonization and forced assimilation, particularly the twentieth-century policies of relocation and termination. The urban relocation program was launched by the 1956 Indian Relocation Act, which encouraged reservation inhabitants to move to the cities, where they were promised "wonderful lives," "good-paying jobs, good schools and good housing" (Nesterak). In a 1950s video distributed by the Bureau of Indian Affairs (BIA) to promote relocation, "Native men are shown welding, cutting hair, and even preparing lobsters in white chef's outfits," (Nesterak) while mothers and children are shown watching television and enjoying the conveniences of their modern urban homes (Nesterak). The federal government committed to helping Native relocatees with traveling expenses, offered them vocational training, subsistence per diem in the first four weeks of living in the cities, health insurance, as well as funds to purchase, among other things, houses and household goods. As a result, the reservations became extremely impoverished in the 1950s, most of the households having no electricity or running water, their facilities being in disrepair, their life expectancy only 44 years, and infant mortality 
"several times higher than elsewhere in the nation" (Nesterak), thousands of individuals opted to move from the reservations to the cities. Yet, upon their arrival, they realized that very few of the promises came true. Housed in the so-called "redlined areas," where jobs were few and wages were low, the new urban Natives had to deal with segregation at the job market, poverty, and cultural shock. As they struggled through the workweek, the relocated Indians "realized that grasping at the dream of success could never assure the reality of success," (Clark 286) and that their migrant dreams were out of reach. The relocated American Indians were marginalized in every possible way, relegated to the lowest end of the economic and occupational scale:

Urban Indians resided in the most substandard housing, had the least satisfactory sanitary facilities, had the highest rate of illiteracy, commanded the highest rate of diseases per capita, were more often unemployed, and when employed were more often underemployed and received lower wages than all of the other groups in the city. The Indian in the city was among the poorest of poor city dwellers. The urban Indian was only slightly better off economically than his reservation relatives. (Clark 286)

The relocation program worked conjointly with the termination policy that aimed at dissolving sovereign tribes and making all Natives become tax-paying American citizens, in order to fully assimilate them into the mainstream society. Frequently, they relocated individuals and groups belonging to the same tribe to different cities, in order to break down their tribal bonds and discontinue their tradition (Nesterak). The same tactics were used across the U.S. "with tens of thousands of Native families" (Nesterak). While Native relocatees felt detribalized and stranded within an alien zone of liberal capitalism, the governmental agencies portrayed them as incompetent and unable to adjust to work schedules and manage their finances (Lucero 25), thus redlining them, both literally and metaphorically.

Van Alst's Sacred Smokes, where narrator Teddy retells the story of his growing up in Chicago in the 1970s and the 1980s, vividly illustrates the dire consequences of the Indian Relocation Act. In the 1970s, being one of the target cities for relocation, Chicago was home to approximately 12,000 to 16,000 Natives that lived in "a dilapidated eight-square-mile area" on its north side called Uptown (Fixico 20). Teddy is a son of divorced parents and lives with his father, a destructive drunkard who earns very little: "My mom kicked me out of the house when I was thirteen, and my 
brother came along a year or two later" (Van Alst). Teddy's situation is reflective of many urban Native families, as Fixico illustrates, maintained by a single parent, a frequent consequence of domestic violence, unemployment, and substance abuse (8). Inappropriate housing conditions that accentuate a lack of protection for Native families from any kind of outward aggression that home is supposed to offer, are an important background of Teddy's story. Such a situation, as Miller explains, was mostly created by the BIA policies toward Native relocatees (221). Despite the Fair Housing Act of 1968 that forbade discrimination "against any person in terms, conditions, or privileges of sale or rental of dwelling, or in the provision of services or facilities in connection therewith," (Fixico 29) the BIA purposefully channeled the relocatees into substandard housing (Miller 221), and "prejudiced landlords continued to discriminate against Indians," especially those with children, introducing "credit checks, security deposits, and advanced rent," which made housing either unaffordable or extremely uncomfortable (Fixico 29). Places on the north side of Chicago, where Teddy lives with his father and later his brother, indicate the obvious financial neglect. They live in roach-infected motels, "converted SROs," "dumpy apartments," and "tiny studios" (Van Alst). Their first home was an old room at the Hawthorne Terrace hotel with a kitchen, a living room, and a bathroom, where Teddy's father slept on a couch, while Teddy slept in a Murphy bed: "We had these seriously needed Raid $®$ roach motel things ... little boxes lined with glue and you put them along the wall. Roaches check in but they don't check out I think is how the commercial went" (Van Alst). In another apartment, they lived on the third floor with a view of "the gangway across the street, where transvestite hookers take care of business, day, night, and day" (Van Alst), freezing during cold months because of weakly protected windows with "gumball-size holes in the thick frosted glass and the cold air ... pouring right through" (Van Alst).

However, even though their dwelling places, the "derelict houses and the rubble and empty spaces left by demolished 'slums,"' (Moran 34) reflecting the structural inequality and racial segregation of the marginalized groups, completely deviate from the nostalgic imaginary of the domestic space as a sanctuary of intimacy, solitude, comfort, stability, and peace (Moran 28), characters in both novels steadily create alternative homes, demonstrating both the diasporic "homing desire" and "organic" hybrid strategies of self-invention. According to Vincent Descombes, home is, like identity, a rhetorical construct: 
[I]f we pose the question, "Where is (someone) at home?" the answer bears less on a geographical than a rhetorical territory. ... The (person or) character is at home when he is at ease in the rhetoric of the people with whom he shares life. The sign of being at home is the ability to make oneself understood without too much difficulty, and to follow the reasoning of others, without any need for long explanations. (qtd. in Morley 17)

Home is not just a physical place, argues Henri Lefebvre, but is also a representational place - a space of shared narratives of comfort that is "irreducible to a 'form"' (27). In other words, home, like identity, is a narrative, or, as Modarres puts it, a place where "we can invent and reinvent ourselves": "If we consider the act of narration itself the creation of a place within which the narrator constructs an identity, the narration itself becomes a metaphorical, mobile meta-place that allows us to construct and reconstruct our identities" (Modarres 14). Teddy creates such metaphorical meta-places by moving to his best friend, Ids: "Ids was my buddy, my pal, my boy, my best friend. I used to spend the night at his house all the time because my house sucked. That worked out. He always had food, too, so bonus there" (Van Alst). Another alternative meta-place is Teddy's response to deprivation by cooking for himself, using meager supplies at his disposal:

So I was learning how to make shit at home, but running out of options. Eggs. Garlic bread in the broiler. You know, generic white bread with margarine (the old man called it "oleo") and garlic salt.

That was about it. There really wasn't anything else in the house. The old man was cheap that way. He left money on the counter one time for me to buy milk. Two one-dollar bills. Milk cost

$$
\text { \$1.75. (Van Alst) }
$$

According to Mary Douglas, home "is not necessarily fixed in space"; it can also be created "by bringing space under control" (qtd. in Morley 16). As Smyth and Croft remind us in leu of Heidegger's dialectic of space and place - space, both cultural and domestic, is a "discursive arena" in which a "battle for subjectivity" is played out (16). The opposed concepts of "home, or being "homed"' and "homelessness" encode and mirror the historical moment in which identities are constructed. Whereas the former condition represents a "balanced" state "in which humankind is at one with itself," the latter is inextricably tied to modern individual's alienation, the "existential homelessness" (Smyth and Croft 15). 
One of the ways the characters in both novels overcome their experience of alienation, and thereby resolve the paradox of a homeless home, is by becoming urban nomads. Teddy explains it would usually take his father, his brother, and himself "about an hour to move" from one home to another since they owned only a few household goods. - "my books, some my brother had, what was left of the dishes, the beds, and the TV" (Van Alst). After the Hawthorne Terrace hotel, they "move into another place just like it" at 549 West Aldine; then, when Teddy's brother, too, "gets the boot" from his mother, they "move down the hall. To a one-bedroom apartment": "We jam three beds into the bedroom and have a combination living room / dining room / kitchen, plenty of room for the old man to break those dishes.... Eventually we pack up that book, and my books, some my brother had, what was left of the dishes, the beds, and the TV, and we move across the street" (Van Alst). According to Fixico, changing the place of residence is a frequent pattern within urban native community. Since redlined areas never offered permanent housing, Native community in Chicago "averaged 0.45 moves per year or one move every 2.2 years" (28). Oakland natives from There There share the same strategy, proving that while a home is a narrative tied to our sense of self, its physical manifestation may be present "every-where" (Smyth and Croft 15-16): "Urban Indians were the generation born in the city. We've been moving for a long time, but the land moves with you like memory. An Urban Indian belongs to the city, and cities belong to the earth. Everything here is formed in relation to every other living and nonliving thing from the earth. All our relations" (Orange). Opal recalls their mother had "always been crazy, in and out of work, moving us all over Oakland, in and out of our dads' lives, in and out of different schools, in and out of shelters" (47). When their mother decided to take part in the Alcatraz occupation, they had left the only real house they ever had: "Me and Jacquie looked up at the house. It'd been okay, the yellow house. ... The first one we'd been in without either of the dads, so it'd been quiet, and even sweet, like the banana cream pie our mom made the first night we spent there, when the gas worked but the electricity hadn't been turned on yet, and we ate standing up in the kitchen, in candlelight" (47). For Opal and Jacquie, the narrative of the home is recreated in each new place of residence. Even the hotel near the Oakland airport, where they stayed after Jacquie's father left them for good, evokes pleasant memories: 
Their mom told them stories about moving away for good. About getting back home to Oklahoma. But home for Jacquie and her sister was a locked station wagon in an empty parking lot. Home was a long ride on a bus. Home was the three of them anywhere safe for the night. And that night in the hotel, with the possibility of taking a trip, of getting away from the life her mom had been running down with her daughters in tow, that night was one of the best nights of Jacquie's life.

(Orange)

The characters' ability to create what Elaine Savory has termed the "traveling identity" (171) is one of the key diasporic practices in both novels - proving that home, including their Native homeland, is a concept that, albeit emptied of its original meaning, remains inhabited and inhabitable and that, unperturbed by their multiple migrations, it still sustains their sense of communal identity. In Deleuze and Guattari's terms, both Sacred Smokes and There There manifest their characters' "relative deterritorialization" (5) by emphasizing their ability to reterritorialize in their "interior milieu[s]" (332). Comparing his family's urban migrations to the seasonal migrations of his Lakota forebears, Teddy asserts: “It was time to move anyway. ... I always thought to myself, Hey, weren't we nomads, some of the most mobile people of the Plains..." (Van Alst). Urban Indian diaspora's nomadic mode of living, including their "cyclical" migration from cities to visit with relatives, share in tribal experiences, and attend ceremonies (Clark 288), reflects not only its precarious in-between situation but also its ability to resolve it by navigating between two different identity positions and maintaining their diasporic communal and kinship ties. Their mobile identities are thus strongly relational, which confirms that home is a nexus of narratives and collective memories rather than space.

According to Bevis, one of the prominent characteristics of the 1970s and 1980s Native American novels is their "centripetal, converging, contracting" plot (582). The characters in these novels undergo an identity quest that is not premised on individualism, social isolation, and exile, as is the case in the Western tradition, but is, to the contrary, strongly marked by "the homing" pattern (Bevis 582). The "homing" paradigm stands in stark opposition to Euro-American "wandering" plot, the success story of competitive individualism (Bevis 585, 594); it supports "a tribal rather than an individual" (Bevis 585) conception of identity and being, which is "transpersonal" and includes not only "bloodlines" but also the "extended family, clan, community" (591). Its "fulcrum is a sense of 
relatedness" profoundly defined by "society, place, and past" (585-57). Unlike Euro-American characters, who leave their own past behind as their quests entail mobility in both space and time (Bevis 588), Native identity narratives are strongly defined and confined by history. Indeed, in both Sacred Smokes and There There, in one way or another, characters' identities and experiences of Otherness, poverty, violence, and alienation are inseparable from the collective historical trauma of colonization. James Baldwin's quote "People are trapped in history and history is trapped in them" opens the narrative of Opal Viola Victoria Bear Shield. We learn that Opal is full of regrets but "not about things she's done" (Orange). She regrets the bad things that had happened to her: "She regrets that they happened. It doesn't matter that she didn't cause them to happen. She figures she must deserve it in some way" (Orange). "We got bad blood in us," says Octavio's uncle Sixto, a character from There There: "Some of these wounds get passed down ... Some people get diseases passed down in their genes. Some people get red hair, green eyes. We got this old thing that hurts real fucking bad, makes you mean" (Orange). Equally, Octavio's grandmother, Fina, remarks:

Some of us got this feeling stuck inside, all the time, like we've done something wrong. Like we ourselves are something wrong. Like who we are deep inside, that thing we want to name but can't, it's like we're afraid we'll be punished for it. So we hide. We drink alcohol because it helps us feel like we can be ourselves and not be afraid. But we punish ourselves with it" (Orange).

According to Grossberg, "the question of identity is one of social power," and "the self as the material embodiment of identities, the material points at which codes of difference and distinction are inscribed upon the socius, exists only after the inscription of historical differences" (16). As the Prologue of There There reveals, contemporary Native identity remains circumscribed with the historical legacy of colonization and its ramifications.: "They took everything and ground it down to dust as fine as gunpowder ... they fired their guns into the air in victory and the strays flew out into the nothingness of histories written wrong and meant to be forgotten. Stray bullets and consequences are landing on our unsuspecting bodies even now" (Orange). One of those "stray bullets" landed on Tony Loneman, a victim of fetal alcohol syndrome whose face carries the literal scars of the historical trauma inherited at birth: 
Back home, in front of the TV, before I turned it on, I saw my face in the dark reflection there. It was the first time I saw it. My own face, the way everyone else saw it. When I asked Maxine, she told me my mom drank when I was in her, she told me real slow that I have fetal alcohol syndrome. All I heard her say was Drome, and then I was back in front of the turned-off TV, staring at it. My face stretched across the screen. The Drome. ... My eyes droop like I'm fucked up, like I'm high, and my mouth hangs open all the time. There's too much space between each of the parts of my face - eyes, nose, mouth, spread out like a drunk slapped it on reaching for another drink. People look at me then look away when they see I see them see me. That's the Drome too. My power and curse. The Drome is my mom and why she drank, it's the way history lands on a face, and all the ways I made it so far despite how it has fucked with me since the day I found it there on the TV, staring back at me like a fucking villain. (Orange)

Like Tony, Orvil reveals that all his mother ever did was push him and his brothers out: "Jamie is the boys' mom. But all Jamie ever did was push them out. Didn't even quit using when they were in her. The three of them had all begun life in withdrawal. Heroin babies. Jamie shot herself between the eyes when Orvil was six, his brothers four and two" (Orange). The residual effects of colonization seem thus materialized in these characters' bodies and their sense of self, or rather, a lack thereof. Jacquie's daughter Blue, whom her mother gave up for adoption at birth, knows nothing about her Native identity even though she frequently falls victim to hate speech and racial profiling:

Almost all I know about my birth mom is that her name is Jacquie Red Feather. My adoptive mom told me on my eighteenth birthday what my birth mom's name is and that she's Cheyenne. I knew I wasn't white. But not all the way. Because while my hair is dark and my skin is brown, when I look in the mirror I see myself from the inside out. And inside I feel as white as the long white pillshaped throw pillow my mom always made me keep on my bed even though I never used it. I grew up in Moraga, which is a suburb just on the other side of the Oakland hills - which makes me even more Oakland hills than the Oakland hills kids. So I grew up with money, a pool in the backyard, an overbearing mother, an absent father. I brought home outdated racist insults from school like it was the 1950s. All Mexican slurs, of course, since people where I grew up don't know Natives still exist. That's how much those Oakland hills separate us from Oakland. Those hills bend time. ... I didn't do anything about what my mom told me on my eighteenth birthday right away. I sat on it for years. I kept on feeling white while being treated like any other brown person wherever I went. (Orange) 
Like Blue and Dene, who is "is not recognizably Native" and describes himself as "ambiguously nonwhite" (Orange), Edwin Black, son of a white mother who barely remembers his "Native American Indian" father's name, perceives his identity as an absence. Edwin has done a lot of research, desperate to learn "what the other half" of him is:

I'd gotten through four years as a Native American studies major. Dissecting tribal histories, looking for signs, something that might resemble me, something that felt familiar. ... I wrote my thesis on the inevitable influence of blood quantum policies on modern Native identity, and the literature written by mixed-blood Native authors that influenced identity in Native cultures. All without knowing my tribe. ... Always defending myself. Like I'm not Native enough. I'm as Native as Obama is black. It's different though. For Natives. I know. I don't know how to be. Every possible way I think that it might look for me to say l'm Native seems wrong. (Orange)

These characters' ambiguous sense of self mirrors the ambivalent and often contradictory definition of contemporary Native identity, its historical constructedness, or "chaining" ("Who Needs 'Identity'?" 5-6), as Hall has it, by discourses and institutions. According to Jaimes, the Federal government, State governments, and the Census Bureau apply completely different criteria when defining Native identity for statistical purposes, and even Federal criteria are not consistent among agencies (131). The criteria for defining a person as Native diverge from "being grounded in native language and culture, having a valid genealogical heritage as Indian, embracing a worldview derived from traditions, having an idea of one's self as an Indian, and being recognized as an official member of a tribe" (Lucero 35). Whereas financial aid to assist American Indian education is reserved only for people with one-quarter or more Native blood, the law and order regulations count any person of Native descent as Native American. State guidelines are even less congruent. Some "accept the individual's own determination," (Jaimes 132) some accept individuals as Indian should they be recognized as such in their community, some of them are based on the criterion of reservation residence, one state requires one-quarter blood quantum, and the other uses the definition of the Census Bureau that Native Americans are who they say they are (Jaimes 131-32). Whereas the BIA identifies a person as Native American based on one-quarter Indian blood, the tribes have their own criteria that again quite vary from tribe to tribe (Harlan 120), making the idea of Native identity even more complex and ambiguous (Runtić 261). Since three-quarters of 
contemporary registered Natives Americans are of mixed descent (Jacobs 7), many of them are indistinguishable from non-Indians, which particularly applies to urban Indian residents, who often have to deal with the unsettling lack of physical traits of Indianness and are "mistaken for members of other racial and ethnic groups, often Hispanic or Asian" (Harlan 119). Maneuvering between invisibility and visibility in metropolitan "contact zones," like the characters from Van Alst's and Orange's novels, they must negotiate the competing identities handed down to them, "constructed across different, often intersecting and antagonistic, discourses, practices and positions" (Hall, "Who Needs 'Identity'?" 4). Same as Thomas Frank, they are more than of their Indigeneity being a "chip" they carry:

A concrete chip, a slab really, heavy on one side, the half side, the side not white. As for your mom's side, as for your whiteness, there's too much and not enough there to know what to do with. You're from a people who took and took and took and took. And from a people taken. You were both and neither. When you took baths, you'd stare at your brown arms against your white legs in the water and wonder what they were doing together on the same body, in the same bathtub. (Orange)

"Your face is the cover to your book," says Teddy, "And if you look out and off to the side from it, under the scratched-out title, well, no one can read that, can they?" (Van Alst). Our histories profoundly shape our identities and experiences, confirming we are not all equal, explains Thomas. If you were born Native, "Before you were born, you were [also] chased, beaten, broken, trapped on a reservation in Oklahoma... you were your dad's decision to move away from the reservation..." (Orange). If you were born a white person,

... you have the option to not think about or even consider history, whether you learned it right or not, or whether it even deserves consideration, that's how you know you're on board the ship that serves hors d'oeuvres and fluffs your pillows, while others are out at sea, swimming or drowning, or clinging to little inflatable rafts that they have to take turns keeping inflated, people short of breath, who've never even heard of the words hors d'oeuvres or fluff. Then someone from up on the yacht says, "It's too bad those people down there are lazy, and not as smart and able as we are up here, we who have built these strong, large, stylish boats ourselves, we who float the seven seas like kings." (Orange) 
According to Aloma, unlike some other types of trauma, such as PTSD, historical trauma (HT) is "cumulative" and has an "intergenerational effect," so that the "descendants of individuals who have experienced HT are ... more susceptible to pathological dysfunction" (28-29). Historical trauma is especially severe among the urban Natives whose alienation from their tribal community and traditional ways of healing reduces their ability to deal with the wound in order not to repeat it (Aloma 33). A character from There There explains: "How you ended up getting fired was related to your drinking, which was related to your skin problems, which was related to your father, which was related to history. The one story you were sure to hear from your dad, the one thing you knew for sure about what it means to be Indian, was that your ... Cheyenne people ... were massacred at Sand Creek" (217). Accordingly, both Sacred Smokes and There There demonstrate that "The wound that was made when white people came and took all that they took has never healed," that "[a]n unattended wound gets infected," that it "[b]ecomes a new kind of wound like the history of what actually happened became a new kind [of] history" (Orange). As a result, their characters' growth seems defined, and mainly paralyzed, by the unresolved residue of the "colonial wound," (cf. Mignolo 3) demonstrating that the contemporary Native diasporic sense of being is not "eccentric" or "centrifugal" but is always necessarily "centripetal" (cf. Bevis 582) as one's present is "constantly shadowed by a past" (Clifford 318)! ${ }^{[1]}$

Some of the practices that Native characters in There There and Sacred Smokes employ to resolve their precarious diasporic position include the creation of alternative relational forms of cultural interaction or, what Tölölyan terms, diasporic forms of "memory and (dis)identification" (qtd. in Clifford 304) - connecting with "multiple communities of a dispersed population" (Tölölyan qtd. in Clifford 304) and forming "decentered, lateral connections" with those who share their "ongoing history of displacement, suffering, adaptation, or resistance" (Clifford 306). Teddy forms such diasporic attachments with other children of color from his neighborhood, with whom he shares the experience of ghettoization and the gang identity: “... we can see a bunch of gangbangers in the parking lot by the bank. Like us. Wearing baggies. No shirts. Everybody good and browned up. After a couple weeks of Chicago sun, summer, like poverty, makes us all the same color" (Van Alst). These liaisons serve as a personal leeway that he frequently resorts to, especially when his father is at "home, and it's day, and [he has] been drinking" (Van Alst). This way, paradoxically, he 
builds a "safe" niche and transcends the anxieties of financial neglect and domestic aggression by resorting to equally violent and dangerous delinquent gang behavior. Being often on the streets, Teddy knows every hole, cheap pizza place, cheap movie-theatre, bus or train route, but he is also familiar with "every set, every gang":

We hung together strong all day long and drank and smoked and listened to tunes and talked shit and beat each other's asses. But there were times when all that was a lot, and l'd sit on the guardrail next to the street across from this weird hippy community-type garden they kept planting and we kept stealing from. ... Some days there would be carrots, but some days we'd have to go try and get apples and wild grapes from the grounds of this Catholic girl's school - behabited lunatics from the in-house nunnery would chase us away with what everyone said was a German shepherd whose teeth the good sisters had had removed but none of us wanted to find out, and I would try to imagine my life burning across the sky. (Van Alst)

Despite the hopelessness, violence, and abuse he witnesses on a daily basis, Teddy realizes that the street community offers him a cohesive mode of group identification, a form of urban tribalism, demonstrated in particular by its older members:

Those older guys ... who had done time, those were probably some of the best people l've ever known in my life, even now. Generous, thoughtful, always looking out for other people. If there's an underappreciated group of folks just trying to make it all work, it's them. That trying to keep it together, make sense of it all, that takes a daily want. Something you need to renew. (Van Alst)

Teddy also forms lateral connections with other Lakotas from Chicago, some of whom he meets on the Broadway bus:

Hey little brother, they would say, whatcha readin' now? while we sat in the back and they would laugh into their hoodies and talk shit and be loud and hold on tight to their big lunch buckets on their way to work. They had big glasses like me, and crappy skin, ditto, and would say 'later' when they got off further down the line and head-up nod, not head-down nod like everyone else. When they stopped getting on the bus, I went back to taking the El. (Van Alst) 
These Lakota "uncle dudes" (Van Alst), with whom he shares the strategies of urban survival rather than the "teleology of origin/return" (Clifford 306), also function as his surrogate family, a form "of community consciousness and solidarity that maintain[s] identifications outside the national time/space in order to live inside, with a difference" (Clifford 308).

According to Clifford, diasporic forms "encode practices of accommodation with, as well as resistance to, host countries and their norms" (307):

The nation-state, as common territory and time, is traversed and, to varying degrees, subverted by diasporic attachments. ... Peoples whose sense of identity is centrally defined by collective histories of displacement and violent loss cannot be 'cured' by merging into a new national community. This is especially true when they are the victims of ongoing, structural prejudice.

(Clifford 307)

In There There, such diasporic attachments are manifested in the traditional forms of social gathering, in particular the powwow, a contemporary phenomenon that represents both an intertribal platform and a bridge between urban and non-urban Native communities, bringing traditional gatherings to those who are "one foot in Indian Country, one in non-Indian terrain" (Harlan 76). One of the main characteristics of powwows is their hybrid pan-Indian character: "On the powwow field, a dancer of one tribe might have borrowed the bead work design or feather work of his neighbor from another tribe. An Indian woman from the Pacific Northwest participated in a plains-style powwow, even though that was not her home tradition" (Clark 289). The powwow culture is also instrumental in reasserting the relational kernel of Native urban identity. What appears "to an outsider as a self-indulgent social gathering done to the hypnotic repetition of a drum [is] in reality a method that [builds] an ethnic identity, [breaks] social isolation, [passes] on traditions to youth, and [reaffirms] religious bonds" (Clark 289). The scattered individuals and families that meet and form specific intertribal "Native ghettoes," as Fixico calls them, (re)create new structures, scenes, and "home spaces like those left on the reservation" in which they feel "comfortable among each other"; these are "reservations of space in cities" (Fixico 31). As yet another surrogate domestic space, powwow thus serves as a "new tribal" diasporic form that maintains what Clifford terms "the collective life," and the connection with the "autochthonous" 
community, thus helping to "bypass an opposition between rootedness and displacement" that inevitably leads to "destruction of autochthonous attachments by global forces" in a diasporic environment (Clifford 309-10). In like manner, the Big Oakland Powwow serves as the most important signal of "homing" in There There:

We made powwows because we needed a place to be together. Something intertribal, something old, something to make us money, something we could work toward, for our jewelry, our songs, our dances, our drum. ... We keep powwowing because there aren't very many places where we get to all be together, where we get to see and hear each other. ... For powwows we come from all over the country. From reservations and cities, from rancherias, forts, pueblos, lagoons, and offreservation trust lands. ... To get to powwows we drive alone and in pairs on road trips; we caravan as families, piled in station wagons, vans, and in the backs of Ford Broncos. ... we sing, pray, and tell stories until we run out. We lie, cheat, and steal our stories, sweat and bleed them out along the highway. ... We've been coming from miles. And we've been coming for years, generations, lifetimes, layered in prayer and handwoven regalia, beaded and sewn together, feathered, braided, blessed, and cursed. (Orange)

The powwow is also the main signal of what Krupat terms the "synecdochic" self. According to Krupat, unlike modern Western identity, which is essentially "metonymic"; premised on part-to-part relations and necessary separation between the individual and society, "Native American conceptions of the self tend toward integrative rather than oppositional relations with others" and may be described as "synecdochic," i.e., based on part-to-whole relations (Introduction 4; Ethnocriticism 216, 220). Describing the drum groups and the dancers, Orvil experiences the powwow's "synecdochic" centripetal force. He admires how the chorus, in powerful unison of voices, merges one's individual voice, experience, pain, history with that of the group, how it "sometimes ... sounds like ten singers, sometimes like a hundred": "You want to drum but also to be heard drumming. Not as yourself but just as the drum" (Orange). While dancing in Opal's room with his eyes closed, Orvil feels "like it was all his ancestors who made it so he could be there dancing and listening to that sound, singing right there in his ears through all those hard years they made it through" (Orange). Regardless of the confusing final powwow shooting episode, the Big Oakland Powwow setting serves as an ultimate meta(narrative) - a space that gives coherence to characters and their fractured "narrative wisps," allowing them to recognize their shared sense of 
identity or, in the case of Edwin and Blue, their literal blood ties. In other words, it becomes a locus of "organic" hybridity in which the "dangling strands" of urban Indian identity "[get] pulled into a braid - tied to the back of everything [they]'d been doing all along" (Orange). As Hall reminds us, cultural identity is a

... matter of "becoming" as well as of "being." It belongs to the future as much as to the past. ... Cultural identities come from somewhere, have histories. But like everything which is historical, they undergo constant transformation. Far from being eternally fixed in some essentialised past, they are subject to the continuous "play" of history, culture and power. Far from being grounded in mere "recovery" of the past, which is waiting to be found, and which when found, will secure our sense of ourselves into eternity, identities are the names we give to the different ways we are positioned by, and position ourselves within, the narratives of the past. (Hall, "Cultural Identity and Diaspora" 52)

The repositioning of urban Indian identity through its constant reinvention and adaptation is one of the dominant themes in both Sacred Smokes and There There. Aware his options are limited, and having to leave the ghetto, Teddy realizes that "the only way to make a different difference," and survive, is to re-envision himself: "I didn't know then what I needed to do, but I knew this, all this, was fucked, wasn't for me, would kill me dead if I let it, and I wasn't ready to die just then" (Van Alst). In like manner, mapping new subject positions by envisioning new patterns of homing and belonging, the urban Indian diaspora in There There sustains the "synecdochic" core of Native identity through its adaptation and transformation:

Getting us to cities was supposed to be the final, necessary step in our assimilation, absorption, erasure, the completion of a five-hundred-year-old genocidal campaign. But the city made us new, and we made it ours. We didn't get lost amid the sprawl of tall buildings, the stream of anonymous masses, the ceaseless din of traffic. We found one another, started up Indian Centers, brought out our families and powwows, our dances, our songs, our beadwork. We bought and rented homes, slept on the streets, under freeways; we went to school, joined the armed forces, populated Indian bars in the Fruitvale in Oakland and in the Mission in San Francisco. We lived in boxcar villages in Richmond. We made art and we made babies and we made way for our people to go back and forth between reservation and city. We did not move to cities to die. The sidewalks and streets, the concrete, absorbed our heaviness. The glass, metal, rubber, and wires, the speed, the hurtling 
masses - the city took us in. We were not Urban Indians then. This was part of the Indian Relocation Act, which was part of the Indian Termination Policy, which was and is exactly what it sounds like. Make them look and act like us. Become us. And so disappear. ... They used to call us sidewalk Indians. Called us citified, superficial, inauthentic, cultureless refugees, apples. An apple is red on the outside and white on the inside. But what we are is what our ancestors did. How they survived. We are the memories we don't remember, which live in us, which we feel, which make us sing and dance and pray the way we do, feelings from memories that flare and bloom unexpectedly in our lives like blood through a blanket from a wound made by a bullet fired by a man shooting us in the back for our hair, for our heads, for a bounty, or just to get rid of us.

(Orange)

In the manner of his favorite toys, Transformers, "made of metal, made hard, able to take it" (Orange), Tony Loneman, whose narrative voice opens and ends There There, develops "street smarts" to protect himself in the urban jungle: "I know if someone's selling around me. I know Oakland. I know what it looks like when somebody's trying to come up on me, like when to cross the street, and when to look at the ground and keep walking" (Orange). Paradoxically, in order to preserve his Indianness and remain what he is, like one of his Transformers, Optimus Prime, Tony must change:

The process that brings anything to its current form - chemical, synthetic, technological, or otherwise - doesn't make the product not a product of the living earth. Buildings, freeways, cars are these not of the earth? Were they shipped in from Mars, the moon? Is it because they're processed, manufactured, or that we handle them? Are we so different? ... Urban Indians feel at home walking in the shadow of a downtown building. We came to know the downtown Oakland skyline better than we did any sacred mountain range, the redwoods in the Oakland hills better than any other deep wild forest. We know the sound of the freeway better than we do rivers, the howl of distant trains better than wolf howls, we know the smell of gas and freshly wet concrete and burned rubber better than we do the smell of cedar or sage or even fry bread - which isn't traditional, like reservations aren't traditional, but nothing is original, everything comes from something that came before, which was once nothing. Everything is new and doomed. We ride buses, trains, and cars across, over, and under concrete plains. Being Indian has never been about returning to the land. The land is everywhere or nowhere. (Orange) 
For Tony and his generation, contemporary technologies and media are the main vehicles for maintaining tradition through change and "freedom to reimagine themselves" (Owens 27). Both Tony and Orvil embrace the television and the Internet as new pan-Indigenous diasporic spaces "Inside the high-rise of multiple browser windows" (Orange) in which identity is negotiated in unexpected ways: "And virtually everything Orvil learned about being Indian he'd learned virtually. From watching hours and hours of powwow footage, documentaries on YouTube, by reading all that there was to read on sites like Wikipedia, PowWows.com, and Indian Country Today. Googling stuff like 'What does it mean to be a real Indian' ..." (Orange). The first time he sees a Native dancer on television, Orvil is fascinated and instantly knows that he wants to be a dancer too. Eventually, he learns how to dance "by watching powwow footage on YouTube" (Orange):

Everyone else had gone to bed. He was flipping through channels when he found him. There on the screen, in full regalia, the dancer moved like gravity meant something different for him. It was like break dancing in a way, Orvil thought, but both new - even cool - and ancient-seeming. There was so much he'd missed, hadn't been given. Hadn't been told. In that moment, in front of the TV, he knew. He was a part of something. Something you could dance to. (Orange)

Orvil's comparison of traditional dancing to breakdance manifests hybridity in both its organic and diasporizing form, as it locates new spaces and structures by maintaining the tradition through its displacement, "translation," and "transformation" (Young 23). "The problem with Indigenous art in general is that it's stuck in the past," maintains Edwin Black: "If it isn't pulling from tradition, how is it Indigenous? ... And if it is stuck in tradition, in the past, how can it be relevant to other Indigenous people living now, how can it be modern?" (Orange). Yet, for the characters of There There, contemporary virtual culture seems to offer a solution to this double bind. Describing his favorite band, A Tribe Called Red, a group of First Nations producers and DJs from Ottawa who "make electronic music with samples from powwow drum groups," Ed reveals that their music is

the most modern, or most postmodern, form of Indigenous music [he has] heard that's both traditional and new-sounding": "... to get close to but keep enough distance from tradition, in order to be recognizably Native and modern-sounding, is a small kind of miracle these three First 
Nations producers made happen on a particularly accessible self-titled album, which they, in the spirit of the age of the mixtape, gave away for free online" (Orange).

Hybridity, explains Cristina-Georgiana Voicu, refers to a moment in which "a thing becomes its alterity" (28). Hybrid identity positions itself as "lubricant" by creating an "interruptive, interrogative, and enunciative" space in which the production of "anti-monolithic models of cultural exchange and growth" is not only possible but also imminent (Voicu 28). By turning the contemporary technology and the new media into yet another site of diasporic self-imagination, characters of There There manifest both the destabilizing and the regenerative nature of hybridity, confirming Vizenor's belief that dynamism, "continued invention," "transformative powers of the imagination," and metamorphosis are the central components of any cultural self-definition (Zamir 420) and, we would add, cultural survival.

To conclude, although their diasporic experience marks the characters of Sacred Smokes and There There as necessarily deterritorialized, transcultural, and decentered, by positioning their identity narratives at the intersection of the domestic, the historical, and the communal, both texts maintain and expand on the literary tradition of "survivance." Emphasizing the narrative foundations of the urban Indian identity, as well as the fact that it can only be sustained through its own translation, repositioning, and reinvention, the two texts demonstrate both the organic and the diasporizing modes of hybridity - its potential to create new forms by means of subversion and transformation. The construction of traveling identities and "reterritorialized" surrogate domestic scenes is one of the key diasporic practices in both novels, proving that home is not just a physical place but that, like one's sense of self, and tribal identity for that matter, it is also a narrative premised on imagination. The protagonists' individual experiences of deprivation, structural inequality, and segregation and the concomitant cycle of domestic dysfunction, depression, and alienation are inseparable from the collective historical trauma related to colonization, whose residual scars compromise them both externally and internally. In that sense, oxymoronically, history serves both as a generator of existential paralysis and yet another signal of homing - an inexorable centripetal force that unites these characters in their shared subaltern situation. The alternative identities Van Alst's and Orange's urban Indians struggle to invent, as they negotiate the conflicting diasporic subject positions, are always strongly transpersonal, nurturing a sense of 
home through lateral attachments, informed by pan-Indigenous and pan-ethnic alliances, extended kinship forms of group identification, or new forms of diasporic networking provided by the globalized digital culture. These relational liaisons root them in the "synecdochic" core of the Native tradition, proving that in order for the memory of home not to be just a myth, like identity itself, it requires continuous rearticulation, reimagination, and transformation.

\section{Works Cited}

Aloma, Alina. Exploring Proximal and Distal Psychosocial Stressors Influencing the Health Outcomes of Urban American Indians in the Midwest. 2016. U of Wisconsin-Milwaukee, PhD dissertation. dc.uwm.edu/etd/1331. Accessed 22 Apr. 2020.

Bevis, William. "Native American Novels: Homing In." Recovering the Word: Essays on Native American Literature, edited by Brian Swann and Arnold Krupat, U of California P, 1987, pp. 580621.

Browdy de Hernandez, Jennifer. "Writing (for) Survival: Continuity and Change in Four Contemporary Native American Women's Autobiographies." Wicazo SA Review, vol. 10, no. 2, 1994, pp. 40-63.

Clark, Blue. "Bury My Heart in Smog: Urban Indians." American Indian Experience: A Profile, edited by Philip Weeks, Forum P, 1988, pp. 278-92.

Clifford, James. "Diasporas." Cultural Anthropology, vol. 9, no. 3, 1994, pp. 302-38.

Cullum, Linda. "Survival's Song: Beth Brant and the Power of the Word." MELUS, vol. 24, no. 3, 1999, pp. 129-40.

Deleuze, Gilles, and Felix Guattari. A Thousand Plateaus: Capitalism and Schizophrenia.

Translated by Brian Massumi, U of Minnesota P, 1987.

Fixico, Donald. Daily Life of Native Americans in the Twentieth Century. Greenwood Press, 2006. Grossberg, Lawrence. "Identity and Cultural Studies - Is That All There Is?" Questions of Cultural Identity, edited by Stuart Hall and Paul Du Gay, Sage Publications, 2000, pp. 81-108. 
Hall, Stuart. "Cultural Identity and Diaspora." Identity and Difference, edited by Kathryn Woorward, Sage Publications, 2002, pp. 51-59.

Hall, Stuart. "Who Needs 'Identity’?" Questions of Cultural Identity, edited by Stuart Hall and Paul Du Gay, Sage Publications, 2000, 1-17.

Harlan, Judith. American Indians Today: Issues and Conflicts. Franklin Watts, 1987.

Holm, Tom, et al. "Peoplehood: A Model for the Extension of Sovereignty in American Indian Studies." Wicazo Sa Review, vol. 18, no. 1, 2003, pp. 7-24.

Jacobs, Connie A. The Novels of Louise Erdrich: Stories of Her People. Peter Lang, 2001.

Jaimes Annette M. "Federal Indian Identification Policy: A Usurpation of Indigenous Sovereignty in North America." The State of Native America: Genocide, Colonization, and Resistance, edited by Annette M. Jaimes, South End P, 1992, pp. 123-39.

Krupat, Arnold. Ethnocriticism: Ethnography, History, Literature. U of California P, 1992.

---, Introduction. Native American Autobiography: An Anthology (Wisconsin Studies in American Autobiography), edited by Arnold Krupat, U of Wisconsin P, 1994, pp. 3-18.

Lefebvre, Henri. The Production of Space. Translated by Donald Nicholson-Smith, Blackwell, 1991.

Lucero, Nancy Marie. Creating an Indian Space in the City: Development, Maintenance, and Evolution of Cultural Identity and Cultural Connectedness Among Multiple Generations of Urban American Indians. 2009. U of Denver, PhD dissertation. digitalcommons.du.edu/etd/864/. Accessed 22 Apr. 2020.

Mignolo, Walter. "Coloniality: The Darker Side of Modernity." Modernologies: Contemporary Artists Researching Modernity and Modernism, edited by Sabine Breitwisser, MACBA, 2009, pp. 39-49. Miller, Douglas K. Reservation Limits: American Indian Urbanization and Uplift in the Twentieth Century. 2014. U of Oklahoma, PhD dissertation.

Modarres, Andrea M. Locating Identities: Narratives of Place in Multiethnic, Immigrant and Diasporic Literature. 2013. U of Arizona, PhD dissertation. hdl.handle.net/10150/308904. Accessed 22 Apr. 2020. 
Moran, Joe. "Houses, Habit and Memory." Our House: The Representation of Domestic Space in Modern Culture, edited by Gerry Smyth and Jo Croft, Rodopi, 2006, pp. 27-43.

Morley, David. Home Territories: Media, Mobility and Identity. Routledge, 2000.

Nesterak, Max. "Uprooted: The 1950s Plan to Erase Indian Country." APMReports, 1 November 2019, www.apmreports.org/story/2019/11/01/uprooted-the-1950s-plan-to-erase-indian-country. Accessed 14 May 2020.

Orange, Tommy. There There. E-book. Knopf Doubleday Publishing Group, 2018.

Owens, Louis. Mixedblood Messages: Literature, Film, Family, Place. U of Oklahoma P, 1998.

Runtić, Sanja. "Postindian Warrior is in the House: Voicing Survivance in Contemporary Native American Art." Voicing the Alternative: Essays on Language and Literary Studies, edited by Aleksandra Nikčević-Batričević and Marija Krivokapić. Filozofski fakultet Nikšić, 2012, pp. 251-69.

Sarris, Greg. Keeping Slug Woman Alive: A Holistic Approach to American Indian Texts. U of California P, 1993.

Savory, Elaine. "Ex/lsle: Separation, Memory and Desire in Caribbean Women's Writing." MaComère: Journal of the Association of Caribbean Women Writers and Scholars, vol. 1, 1998, pp. 170-78.

Smyth, Gerry, and Jo Croft. "Introduction: Culture and Domestic Space." Our House: The Representation of Domestic Space in Modern Culture, edited by Gerry Smyth and Jo Croft, Rodopi, 2006, pp. 11-26.

Snyder, Michael. "Sacred Smokes (Theodore C. Van Alst, Jr.)." Transmotion, vol. 5, no. 2, 2019, journals.kent.ac.uk/index.php/transmotion/article/view/861/1665. Accessed 20 May 2020.

Stein, Gertrude. Everybody's Biography. Vintage Books, 1973.

Van Alst, Theodore C., Jr. Sacred Smokes. E-book, U of Mexico P, 2018.

Vizenor, Gerald. “Trickster Discourse.” American Indian Quarterly, vol. 14, no. 3, 1990, pp. 277-88. Voicu, Cristina-Georgiana. Exploring Cultural Identities in Jean Rhys' Fiction. De Gruyter Open Ltd, 2014. 
Womack, Craig. "Theorizing American Indian Experience." Reasoning Together: The Native Critics Collective, edited by Craig Womack et al., U of Oklahoma P, 2008, pp. 353-410.

Wong, Hertha D. Sending My Heart Back Across the Years: Tradition and Innovation in Native American Autobiography. Oxford UP, 1992.

Young, Robert J. C. Colonial Desire: Hybridity in Theory, Culture and Race. Routledge, 2005.

Zamir, Shamoon. "Rev. of Fugitive Poses: Native American Indian Scenes of Absence and

Presence, by Gerald Vizenor.” Modern Language Quarterly, vol. 61, no. 2, 2000, pp. 419-21. 
[1] For an opposite interpretation, which juxtaposes Teddy's identity narrative to Benjamin Franklin's Autobiography and the trajectory of the American Dream, see: Snyder.

\section{(c) $($ (i) (9)}

Creative Commons Attribution-NonCommercial-NoDerivatives 4.0 International License 